\title{
PATTERNS OF VARIATION IN THE LIMNOLOGY OF SPANISH RESERVOIRS: A REGIONAL STUDY
}

\author{
J. L. Riera, D. Jaume, J. de Manuel, J. A. Morgui and J. Armengol \\ Departament d'Ecologia, Universitat de Barcelona. Avgda. Diagonal, 645, 08028 Barcelona, Spain.
}

Keywords: Regional limnology, Multivariate analysis, Ionic composition, Nutrients, Seston, Plankton, Biogeography.

\begin{abstract}
In this paper, an overview of the major patterns of variation in the limnology of Spanish reservoirs is provided, based on two regional studies carried out in 1972-76 and 1987-88. Geology and climate largely determined the ionic composition of Spanish reservoirs, whereas land uses in the cathment area seem to control nutrient concentrations. Nitrogen and phosphorus, however, presented an independent distribution. While the concentration of nitrate correlated with the mineral content of the water, phosphorus appeared to be associated with seston both during the mixing and the stratification period. Algal biomass was best correlated with phosphorus in summer, but the phosphorus-chlorophyll- $a$ relationship was influenced by the alkalinity and the total nitrogen concentration of the water and, to a lesser extent, by the residence time of the water and the mean biomass of herbivorous crustaceans. Multivariate analysis of phytoplankton, rotifers and crustaceans abundance data consistently revealed the significance of three factors of variation, namely, (1) the ionic composition of the water, (2) the nutrient content, and (3) the water residence time of reservoirs. Together with these ecological factors, historical processes of colonization help explain the geographic distribution of a number of taxa in the reservoirs of Spain, where other limnenic habitats are scarce. Because reservoir ecosystems are recent, colonization is still in progress, as is reflected by the expanded distribution of some taxa in the 1987-88 survey with respect to the previous one.
\end{abstract}

\section{INTRODUCTION}

Spain is a country of low and variable water resources. Genuine lakes are almost absent: apart from Lake Sanabria, a glacial lake in NW Spain, and Lake Banyoles (NE Spain) and a few other smaller karstic lakes, freshwater bodies are only abundant in mountain ranges (Sierra Nevada, Pyrenees) where they originated from glacial activity. Small lagoons and temporal ponds, however, are profusely disseminated throughout the country (ALONSO, 1985). On the other hand, rivers, particularly in the extensive mediterranean areas of the Iberian Peninsula, show high fluctuations in discharge. While they are generally dry in summer, autumnal storms occasionally cause them to flow in spates.

Either because of water shortages or because of hazardous excesses, management of water resources has always been a sorely felt necessity in Spain (PEREZ PICAZO \& LEMEUNIER, 1990). Some of the oldest reservoirs in the world that are still in use are found here: Cornalbo and Proserpina, both near the roman town of Mérida (Badajoz), date from the II century, Almansa (Albacete) was first built in the XIV century, and Tibi, among others, in the XVI century. Extensive construction of reservoirs, however, did not begin until this century, when technological developments permitted it, and it has augmented steadily acompanying, and being stimulated by, economic progress (PEREZ PICAZO \& LEMEUNIER, 1990). Today nearly 1,000 reservoirs are in use in Spain, with a total capacity approaching $45-10^{9} \mathrm{~m}^{3}$ (fig. 1). Apart from water supply, irrigation, and flood control, reservoir uses that predominate in the mediterranean areas, many dams were built for hydropower generation in mountainous areas and in the rainy northwestern region of the country.

Systematic research on Spanish reservoirs did not begin until the late sixties and early seventies, with the work of Vidal on the limnology of Sau Reservoir (NE Spain) (VIDAL 1969, 1973), and gained impetus after a regional study of one hundred reservoirs was undertaken by a research group from the Department of Ecology of the University of Barcelona, under the direction of Ramon Margalef

Limnetica, 8: 111-123 (1992)

(C) Asociación Española de Limnología, Madrid. Spain 


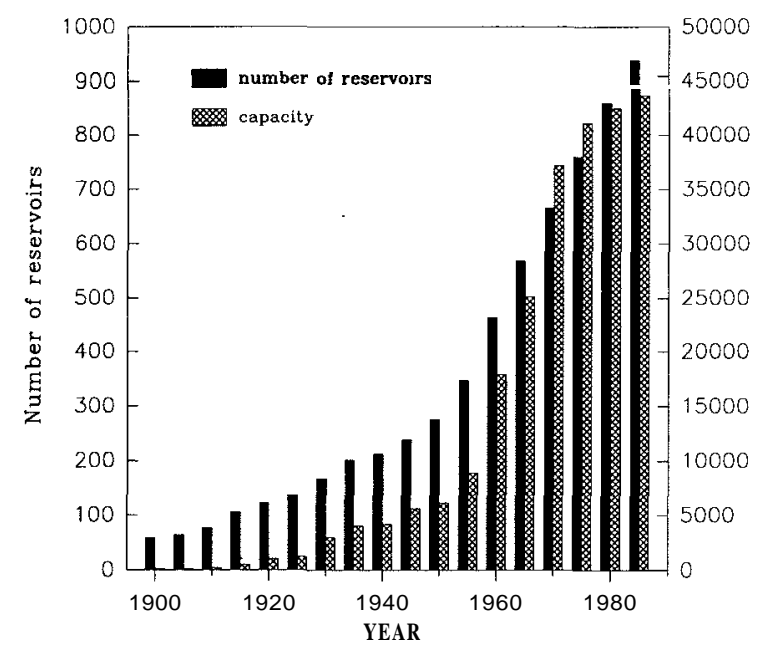

Figure 1. Evolution of the number and total storage capacity of Spanish reservoirs during the 20th century. (Data obtained from Dirección General de Obras Hidráulicas, 1988).

(MARGALEF et al., 1976). Their work set the stage for a number of studies that have addressed more specific aspects of reservoir limnology in different man-made lakes throughout the country (MOYA, 1981; ALVAREZ COBELAS, 1982; ORTIZ \& PEÑA, 1984; TOJA, 1984; GALVEZ et al., 1989). While specific research continued, it was considered advisable to update Margalef's regional study. This

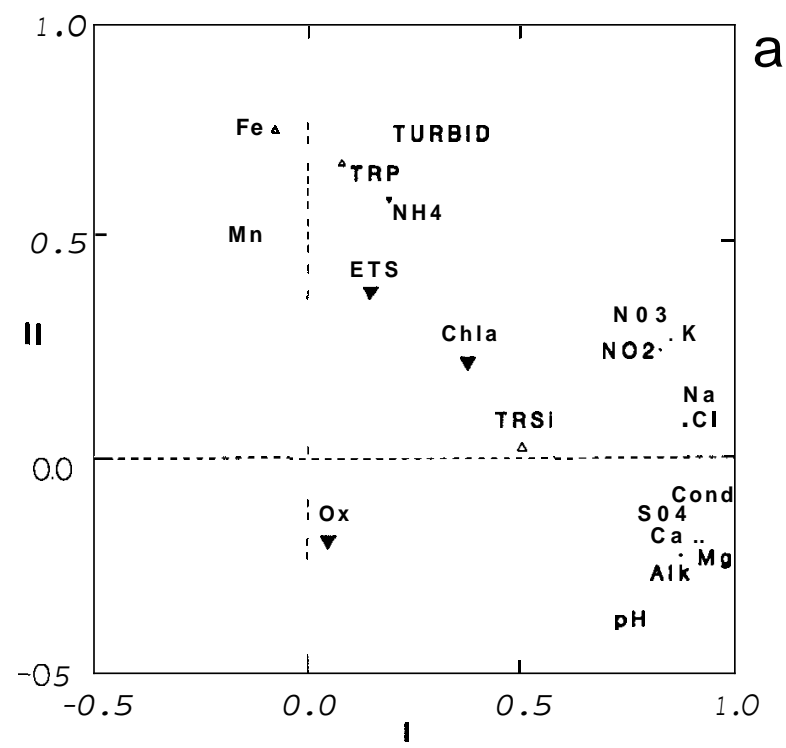

was done in 1987-88, when the same one hundred reservoirs were sampled again.

Our aim here is to delineate the major features of the regional limnology of Spanish reservoirs. Information presented comes basically from the ongoing analysis of the 1987-88 regional study, as well as from the previous study of MARGALEF et al. (1976), and has only been partially published. We will attempt to make apparent the coherence of some basic patterns of variation across different levels of analysis, from the water chemistry through the distribution of organisms.

\section{THE OBSERVATION SET: STUDY SITES, SAMPLING DESIGN AND METHODOLOGY.}

Since the scope of any research project is largely determined by the observation set on which interpretation is done (sensu O'NEILL et al., 1986), and especially by the spatial and temporal scales of sampling (FROST et al., 1988), it is of utmost importance to state here some basic information on the selection of study sites, sampling design and methodology used. Detailed accounts can be found elsewhere (MARGALEF et al., 1976, ARMENGOL et al., 1990b).

One hundred reservoirs were selected so as to represent all major river basins and river districts of Spain, as well as

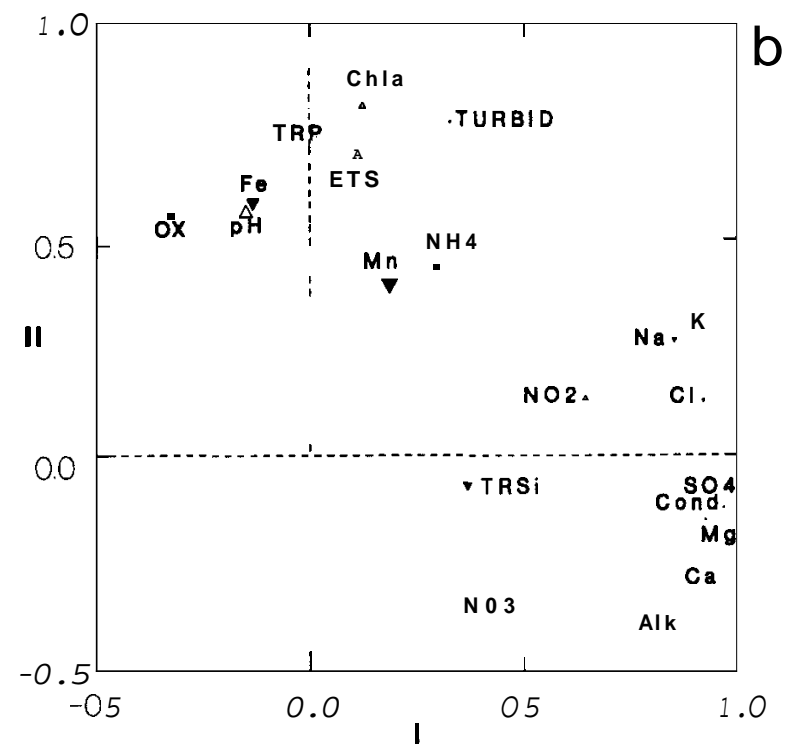

Figure 2. Plol of selected physical-chemical variables in the space detined by the furst and second axes of two Principal Compoiient Analyses performed on (a) winter photic zone averages, and (b) summer photic zone averages. Symbol sizes are proportional to the loadings of each variable on the third axis, open symbols corresponding to positive loadings and full symbols, to negative loadings. OX is the percent oxygen saturation, and TURBID is the inverse of Secchi disk depth (log-transformed). 
Table 1. Summary statistics of a few morphometric variables for the reservoirs studied. Q1 and Q3 are the 25th and the 75th percentiles, respectively.

\begin{tabular}{|c|c|c|c|c|c|c|}
\hline Variable & $\mathrm{N}$ & Min & Q1 & Median & Q3 & $\operatorname{Max}$ \\
\hline Altitude & 101 & 35 & 215 & 364 & 616 & 1111 \\
\hline Max. volume $\left(10^{6} \mathrm{~m}^{3}\right)$ & 101 & 1.5 & 60 & 115 & 318 & 3237 \\
\hline Area $\left(10^{6} \mathrm{~m}^{2}\right)$ & 101 & 0.30 & 3.64 & 7.59 & 14.85 & 104 \\
\hline Max. depth (m) & 101 & 5 & 35 & 54 & 79 & 190 \\
\hline Catchment area $\left(10^{6} \mathrm{~m}^{2}\right)$ & 77 & 130 & 466 & 1438 & 2821 & 82246 \\
\hline Year of construction & 101 & 1883 & 1949 & 1960 & 1967 & 1974 \\
\hline
\end{tabular}

a large variety of reservoir types according to their morphometry and the characteristics of their catchment areas. The geographic location of the study sites is shown in fig 4 . Summary statistics for some selected parameters have been compiled in table 1. Reservoirs ranged widely in morphometry, altitude, position in the river, catchment area and year of construction. Water residence time ranged from less than an hour in the smallest reservoirs to aproximately 12 years. Uses also differed: hydropower was one or the only purpose in 61 reservoirs, irrigation in 52, water supply in 34 and flood control in 3. Most of them, therefore, functioned as multipurpose reservoirs.

Every reservoir was visited on two occasions in 198788 , winter and summer, that roughly correspond to the mixing and stratification periods, and the water column was sampled at a location close to the dam. Table 2 outlines the sampling design. Variables not measured in the previous study included all particulate fractions of nutrients and the activity of the respiratory electron transport system (PACKARD, 1985). Phytoplankton samples were obtained from the same depths, and summer samples from 0 and $5 \mathrm{~m}$. were counted under an inverted microscope after sedimentation. Rotifers were sampled by horizontal and vertical hauls (Nytal net of $40 \mu \mathrm{m}$ mesh size), whereas crustacean samples were taken with a Nytal net of $200 \mu \mathrm{m}$ mesh size.

\section{PATTERNS OF VARIATION IN PHYSICO- CHEMICAL VARIABLES}

\section{Multivariate structure of the data set}

Given the diversity of landscape positions of the reservoirs studied, varying widely in the climate, geology and land uses of their catchments areas, a large variation in physico-chemical parameters could be anticipated. This is summarized in table 3 , where descriptive statistics for selected variables, based on all samples (seasons and depths) are shown. Conductivity varied from 14 to $8920-\mathrm{S} \mathrm{cm}^{-1}$, and all variables associated with the major ionic composition showed analogous variation. Total labile iron and manganese ranged from traces to $142.14 \mu \mathrm{mol} \mathrm{dm}-3$ and from traces to $34.6 \mu \mathrm{mol} \mathrm{dm}^{-3}$, respectively. Nutrients also varied broadly. Total reactive phosphorus (TRP) concentrations ranged from 0.01 to $29.58 \mu \mathrm{mol} \mathrm{dm}^{-3}$, and nitrate from 0.08 to $277.3 \mu \mathrm{mol} \mathrm{dm}^{-3}$. Finally, variables related with particulate organic matter and biomass (particulate organic carbon and nitrogen (POC and PON), chlorophyll- $a$ (Chla) concentration, and the ETS activity at $20^{\circ} \mathrm{C}$ ) showed a correspondingly large variation.

Correlations among variables are best summarized by plotting their loadings on the first axes of a principal component analysis (PCA) (KRZANOWSKI 1988). These are shown in figure 2 for photic zone averages. PCA were performed on correlation matrices of log-transformed variables (with the exception of $\mathrm{pH}$ and percent oxygen saturation). Separate analysis were done for the winter and summer data bases. In both seasons, the first axis appears to be related to the major ionic composition of the water, whereas the second axis groups variables associated with suspended matter and water transparency. Biomass estimates (chlorophyll-u and ETS activity at $20{ }^{\circ} \mathrm{C}$ ) covary with this group in summer, suggesting that suspended matter is primarily composed by biomass in most of the reservoirs during this season. During winter, however, inorganic particles (mainly clays) and detritus seem to determine most of the variability in seston composition, while biomass estimates present high loads on a third, independent axis. 
Table 2. Schematic of the sampling design followed for water physical and chemical analyses during the 1987-88 regional study of Spanish reservoirs. The list of variables measured and analytical techniques used is provided.

\section{SAMPLING DESIGN AND ANALYTICAL TECHNIQUES}

1. In situ meter-by-meter vertical profiles:

- Temperature

- Conductivity

- Dissolved oxygen concentration

2. Analyses done in the field on $0,2,5,10,20 \mathrm{~m}$, bottom water and thermocline water samples

\begin{tabular}{lll}
\hline Variable & Acronym & Analytical technique \\
\hline \hline Dissolved oxygen & $\mathrm{OX}$ & Winkler \\
Hydrogen sulphide & $\mathrm{H} 2 \mathrm{~S}$ & Iodometric method \\
Redox potential & $\mathrm{Eh}$ & Pt \& Ross Reference Electrode \\
$\mathrm{pH}$ & $\mathrm{pH}$ & Ross combination pH electrode \\
Temperature & Temp & Thermistor \\
Alkalinity & Alk & Gran titration \\
Conductivity & Cond & Conductometer
\end{tabular}

3. Water analyses done at the laboratory on samples preserved at $-20{ }^{\circ} \mathrm{C}$.

\begin{tabular}{|c|c|c|}
\hline Variable & Acronym & Analytical technique \\
\hline Sulphate" & S 04 & Ionic Chromatography \\
\hline Chloride $^{\mathrm{a}}$ & $\mathrm{CI}$ & Ionic Chromatography \\
\hline Sodium ${ }^{a}$ & $\mathrm{Na}$ & Atomic Absorption \\
\hline Potassium $^{\mathrm{a}}$ & $\mathrm{K}$ & Atomic Absorption \\
\hline Calcium $^{4}$ & $\mathrm{Ca}$ & Inductively Coupled Plasma \\
\hline Magnesium $^{a}$ & $\mathrm{Mg}$ & Atomic Absorption \\
\hline Iron $^{\mathrm{a}}$ & $\mathrm{Fe}$ & Inductively Coupled Plasma \\
\hline Manganese" & $\mathrm{Mn}$ & Inductively Coupled Plasma \\
\hline Nitrite $^{\mathrm{a}}$ & N02 & Colorimetric method \\
\hline Nitrate $^{\mathrm{a}}$ & N03 & $\mathrm{Cd}-\mathrm{Cu}$ reduction to $\mathrm{N} 02$ \\
\hline Ammonia $^{\mathrm{a}}$ & NH4 & Blue Indophenol \\
\hline Total Nitrogen ${ }^{a}$ & $\mathrm{TN}$ & $\begin{array}{l}\text { Persulphate oxidation to } \mathrm{N} 03 \text {. } \\
\text { Analysis as for } \mathrm{N} 03\end{array}$ \\
\hline Total Reactive Phosphorus" & TRP & Ascorbic acid-molybdate \\
\hline Total Dissolved Phosphorus ${ }^{b}$ & TDP & $\begin{array}{l}\text { Persulphate oxidation to } \\
\text { phosphate. Analysis as for TRP. }\end{array}$ \\
\hline Total Phosphorus" & $\mathrm{TP}$ & $\begin{array}{l}\text { Persulphate oxidation to } \\
\text { phosphate. Analysis as for TRP. }\end{array}$ \\
\hline Total Reactive Silicon ${ }^{\mathbf{a}}$ & TRSi & Colorimetric method \\
\hline Particulate Organic Nitrogen ${ }^{\mathrm{b}}$ & PON & $\mathrm{CNH}$ Analyzer \\
\hline Particulate Organic Carbon ${ }^{\mathrm{b}}$ & POC & $\mathrm{CNH}$ Analyzer \\
\hline $\begin{array}{l}\text { Respiratory Electron Transport } \\
\text { System Activityb }\end{array}$ & ETS & $\begin{array}{l}\text { Formazan reduction (Packard, } \\
\text { 1985) }\end{array}$ \\
\hline Chlorophyll $\mathrm{a}^{\mathrm{b}}$ & Chla & $\begin{array}{l}\text { High Pressure Liquid } \\
\text { Chromatography }\end{array}$ \\
\hline
\end{tabular}

a: analyzed on unfiltered water samples.

b: water filtered through Watman GF/C 


\section{Major ionic composition}

A plot of the values of conductivity against the $\left(\mathrm{Na}^{+}+\mathrm{K}^{+}\right):\left(\mathrm{Ca}^{2+}+\mathrm{Mg}^{2+}\right)$ ratio (fig. 3) shows general agreement with the model of Gibbs (1970). Waters with low conductivity reflect rainfall composition and are dominated by $\mathrm{Na}+$ and $\mathrm{K}^{+}$over $\mathrm{Ca}^{2+}$ and $\mathrm{Mg}^{2+}$. Increasing values of total dissolved solids (TDS) are accompanied by a shift from $\mathrm{Na}^{+}+\mathrm{K}^{+}$to $\mathrm{Ca}^{2+}+\mathrm{Mg}^{2+}$ dominance, reflecting the influence of bedrock geology. Large conductivities, however, are again associated with a dominance of $\mathrm{Na}^{+}+\mathrm{K}^{+}$, revealing the presence of highly soluble saline deposits in the catchment area. These changes in cation dominance are paralleled by patterns of anion dominance: as conductivity increases, either $\mathrm{SO}_{4}{ }^{2-}$ or $\mathrm{Cl}^{-}$take over $\mathrm{HCO}_{3}{ }^{-}+\mathrm{CO}_{3}{ }^{2-}$ as the dominant ions. ARMENGOL et al., (1991) used these differences to characterize Spanish reservoirs according to their ionic composition. In their typology (fig. 4), each reservoir was assigned to one of four groups attending to the TDS content and the relative ionic composition of their waters.

This typology shows how the ionic composition of Spanish reservoirs results from the interaction of geology and climate. Reservoirs assigned to group I, which are distinguished by low conductivity and alkalinity $\leq 1 \mathrm{meq}$ $\mathrm{dm}^{-3}$, are located in eastern Spain, where bedrock is igneous. Reservoirs belonging to group II (alkalinity $>1$ meq $\mathrm{dm}^{-3}$ and anionic composition dominated by bicarbonate) are primarily found in northern Spain, whereas reservoirs in southeastern Spain tend to be classified as group III (dominance of sulphate over bicarbonate). Reservoirs of group IV have in common a high TDS content and a relative ionic composition dominated by chloride, owing to the presence of evaporites in their catchment areas. Saline waters may come from submerged springs, and crenogenic meromixis may occasionally ensue, giving such a reservoir unique characteristics (ARMENGOL et al., 1990b). This geographic pattern is reinforced by a climatic gradient roughly extending from northwestern Spain, characterized by high pluviosity, to the southeast, with high temperatures, high evapotranspiration rates and scarce and variable rain.

A typology is nothing like a rigid classification, and natural variability may result in a reservoir being assigned to different groups at different times. Thus, weather variability (seasonal and interannual) can result in dramatic changes in the ionic composition of some reservoirs. This is particularly true for reservoirs that drain areas of contrasting geology, which receive waters of different characteristics depending on the patterns of rainfall in their catchment area
(ARMENGOL et al., 1990a). The relative ionic composition also changes seasonally (fig. 5) following variations in primary production, which results in the depletion of dissolved inorganic carbon (DIC), the supersaturation of $\mathrm{CaCO}_{3}$ (fig. 6) and, eventually, in the precipitation of $\mathrm{CaCO}_{3}$ from the epilimnion.

\section{Nutrients and seston cornposition}

All of the reservoirs studied were totally mixed when sampled in winter, and algal biomass was generally unimportant (with few exceptions, notably the occurrence of an Anabaena variabilis bloom in Guadalteba reservoir (ARMENGOL et al., 1990b) in February 1988) suggesting that primary production was at the time limited by low temperature and irradiance. In this context, the correlation structure of the physico-chemical data base (fig. 2) may be considered as primarily resulting from processes taking place in the catchment area, and thus a reflection of the geology and land uses therein.

Nitrate and nitrite correlated with the TDS content of the water. Nitrate best regressor was the concentration of potassium, suggesting that they may have a common origin in agricultural runoff and intensive farming. A comparison of nutrient concentrations between 1972-1975 and 1987-88 (RIERA et al., 1991) revealed a significant global increase

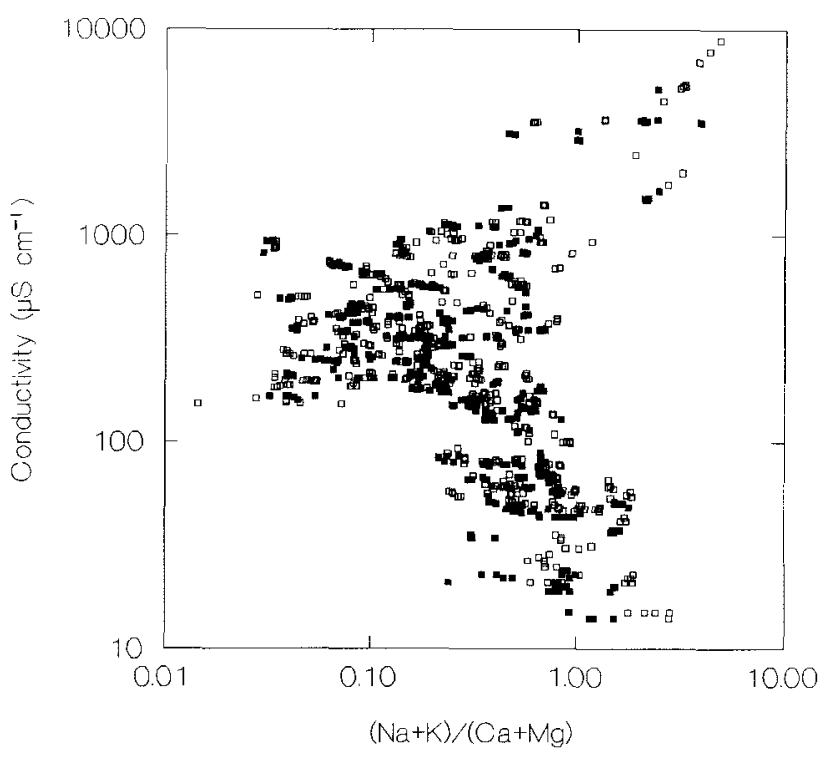

Figure 3. Plot of conductivit) agatsmt the $(\mathrm{Na}+\mathrm{K}) /(\mathrm{C} a+\mathrm{Mg})$ ratio (calculated from concentration values expressed in $\mu$ eq $\mathrm{dm}-3$ ). Values correspond to individual samplea. Full squares represent winter samples and open squares, summer samples. 


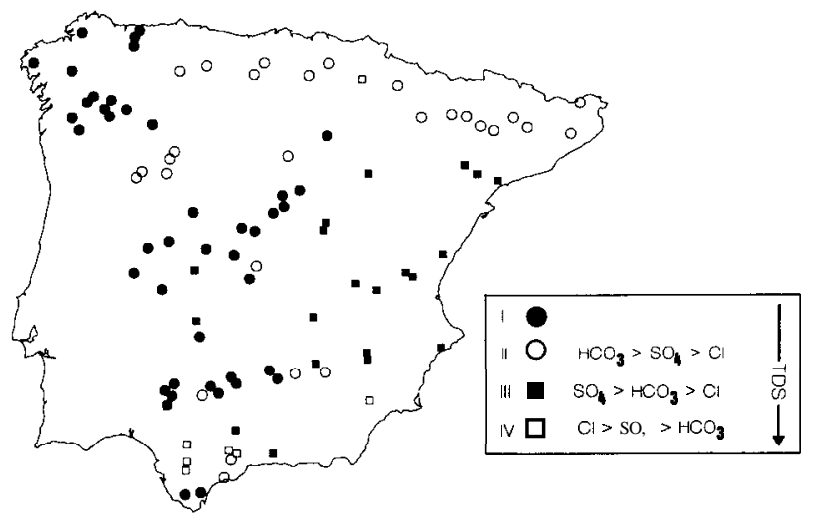

Figure 4. Geographic diatribution of the reservoirs studied. Reservoirs were assigned to one of four groups according to the criteria stated in the figure. See text for further explanation.

in the concentrations of nitrite+nitrate that could be attributed to either increased atmospheric depositions or increased fertilizer application rates in agriculture. Whether the difference observed is a result of interannual variability or reflects a long-term trend cannot be answered with the data on hand, but suggests a question to be addressed by the analysis of a few long-term series.

Whichever the origin of nitrate, its distribution appears to be independent from that of phosphorus. While oxidized forms of dissolved inorganic nitrogen (DIN) correlate with the TDS content of the water, both total reactive phosphorus (TRP) and ammonia appear to be related with suspended matter. TRP in winter was positively correlated with POC, PON, the inverse of Secchi disk transparency and with $\mathrm{Fe}$ and Mn. TRP, Fe and Mn were analyzed on unfiltered water samples and hence include the fraction of those elements that is adsorbed to or co-precipitating with particles. The strong relationship between total labile $\mathrm{Fe}$ and suspended matter is well known (BOYLE et al., 1977; SIGG, 1985). Phosphorus, on the other hand, also adsorbs readily to the surface of particles (STUMM \& MORGAN, 1981; GABELLONE \& GUISANDE, 1989), so that part of the phosphorus measured in winter may be associated with suspended matter and never become available to phytoplankton during the growing season due to its loss by sedimentation. Seston composition also reflects the importance of non-living particulate organic matter during the mixing period in Spanish reservoirs (RIERA \& ARMENGOL, in prep.). While the relationship between Chlorophyll-a and POC is linear in summer (fig. $7 \mathrm{~b}$ ), it deviates from linearity in winter (fig. 7a). Besides, samples with low Chla:POC ratios have the highest iron concentrations (fig. 7a) and the lowest water transparencies.

Even though phosphorus is the best regressor of summer epilimnetic chlorophyll-a (fig. 8a), it is clearly insufficient for any predictive power to be claimed. TP explains only $39 \%$ ( $\mathrm{p}<0.001, \mathrm{n}=73$ ) of the variability in chlorophyll-a, and this percentage is only slightly augmented by incorporation of other regressors. Among these, alkalinity ranks first. Its inclusion is indicative of the role that co-precipitation of phosphorus with calcite may play in these reservoirs, a process for which extensive evidence is available in other ecosystems (OTSUKI \& WETZEL, 1972; LOPEZ \& MORGUI, 1992). Calcite supersaturation is common in eastern, alkaline-water reservoirs in winter, and extends westward in
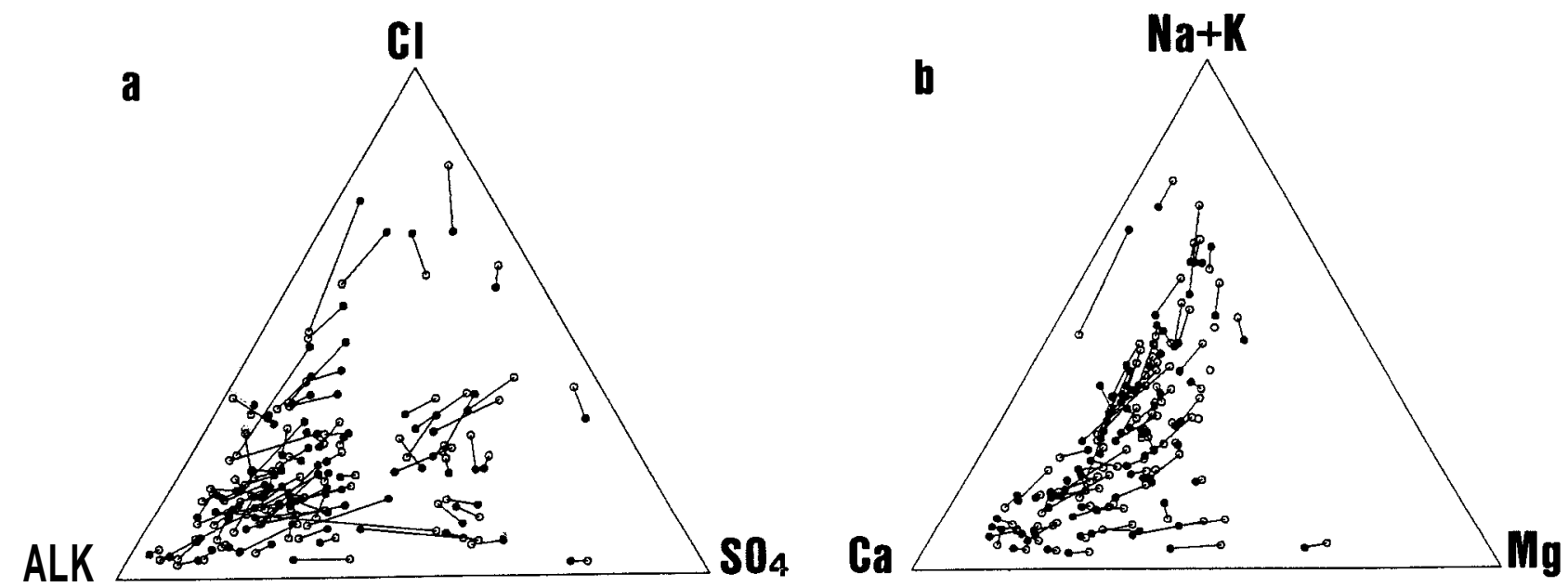

Figure 5. Changes in relative antonic (a)and catonk (b) composition in the reservors studied between wiiiter and aummer $1987-88$. Values are photic zone averages. Full circles correspond to winter samples, and open circles, to summer samples. 

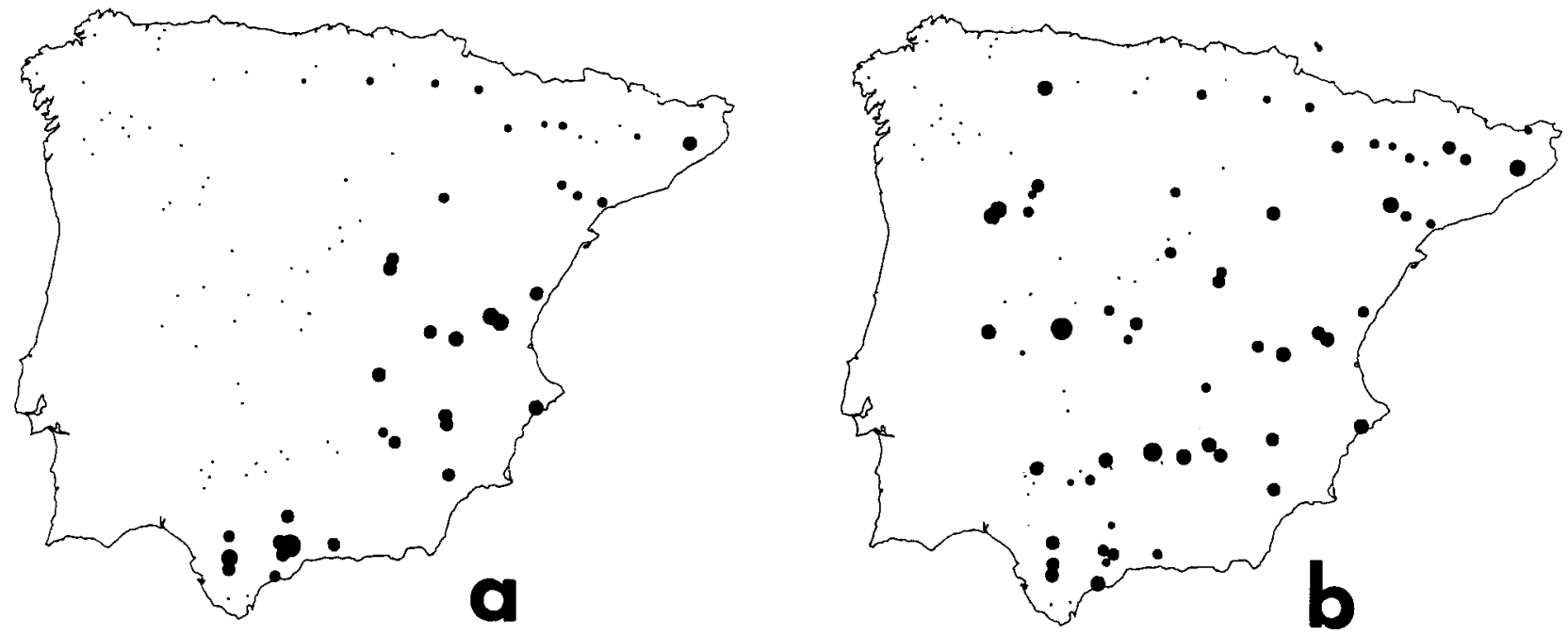

Figure 6. Distribution of phoiic zone averages of the saturatıon index for calcite during (a) u inter and (b) summer. Dols represent undersaturation, whereas circles correspond to supersaturation, the size of the symbol being proportional to the saturation index.

Table 3. Summary statistics for selected physical and chemical variables. Values given were calculated on the entire data set, including all depths and seasons (mixing and stratification).

\begin{tabular}{|c|c|c|c|c|c|c|}
\hline Variable & $\mathrm{n}$ & $\min$ & Q1 & median & Q3 & $\max$ \\
\hline Secchi disk depth (m) & 198 & 0.11 & 1.65 & 2.83 & 4.25 & 8.6 \\
\hline Temperature $\left({ }^{\circ} \mathrm{C}\right)$ & 1143 & 4.7 & 10 & 12.5 & 19.3 & 27.2 \\
\hline Dissolved oxygen (ppm) & 1109 & 0 & 6.97 & 8.71 & 9.72 & 15.7 \\
\hline $\operatorname{Eh}(\mu \mathrm{V})$ & 1141 & -343.0 & 343.9 & 408.09 & 447.6 & 650 \\
\hline Conductivity $\left(\mu \mathrm{S} \mathrm{cm}^{-1}\right)$ & 1143 & 14 & 85 & 247 & 498 & 8920 \\
\hline Alkalinity (peq $\mathrm{dm}^{-3}$ ) & 1141 & 55 & 515 & 1664 & 2784 & 4917 \\
\hline $\mathrm{pH}$ & 1143 & 5.93 & 7.62 & 8.06 & 8.39 & 10.2 \\
\hline Sulphate (peq $\mathrm{dm}^{-3}$ ) & 1134 & traces & 126.6 & 410.2 & 1327.9 & 27873 \\
\hline Chloride (peq $\mathrm{dm}^{-3}$ ) & 1135 & 21.3 & 166.0 & 307.8 & 695.3 & 81001 \\
\hline Sodium (peq $\mathrm{dm}^{-3}$ ) & 1129 & 2.55 & 184.63 & 334.91 & 660.4 & 76574 \\
\hline Potassium (peq $\mathrm{dm}^{-3}$ ) & 1130 & 3.78 & 22.1 & 39.4 & 72.2 & 286.42 \\
\hline Calcium (peq $\mathrm{dm}^{-3}$ ) & 1119 & 14.75 & 377.9 & 1449.4 & 2949.7 & 18243 \\
\hline Magnesium (peq $\mathrm{dm}^{-3}$ ) & 1129 & 12.07 & 175.22 & 477.97 & 1448.1 & 8546 \\
\hline Iron $\left(\mathrm{pmol} \mathrm{dm}^{-3}\right)$ & 1134 & traces & 0.88 & 1.68 & 3.71 & 142.14 \\
\hline Manganese $\left(\mathrm{çmol} \mathrm{dm}^{-3}\right)$ & 1134 & traces & 0.15 & 0.37 & 0.97 & 34.6 \\
\hline Nitrite $(\mathrm{pmol} \mathrm{dm}-3)$ & 1138 & 0.01 & 0.29 & 0.51 & 1.11 & 54.9 \\
\hline Nitrate $\left(\mathrm{pmol} \mathrm{dm}^{-3}\right)$ & 1138 & 0.08 & 10.55 & 26.13 & 54.15 & 277.27 \\
\hline Ammonia $\left(\mathrm{pmol} \mathrm{dm}^{-3}\right)$ & 1128 & 0.01 & 0.58 & 1.94 & 4.62 & 88.3 \\
\hline 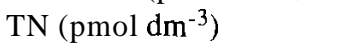 & 1055 & 5.37 & 51.1 & 78.2 & 130.0 & 1291.2 \\
\hline TRP $\left(\mathrm{pmol} \mathrm{dm}^{-3}\right)$ & 1128 & 0.01 & 0.07 & 0.16 & 0.50 & 19.7 \\
\hline $\mathrm{TP}\left(\mathrm{pmol} \mathrm{dm}^{-3}\right)$ & 865 & 0.01 & 0.51 & 0.93 & 2.22 & 29.58 \\
\hline TRSi $\left(\mathrm{pmol} \mathrm{dm}^{-3}\right)$ & 1129 & 0.01 & 6.87 & 22.96 & 45.86 & 843 \\
\hline POC $\left(\right.$ prnol $\left.\mathrm{dm}^{-3}\right)$ & 1102 & 1.75 & 21.17 & 31.46 & 54.75 & 761.1 \\
\hline PON $\left(\mathrm{pmol} \mathrm{dm}^{-3}\right)$ & 1101 & 0.01 & 2.28 & 3.56 & 6.0 & 62.7 \\
\hline $\operatorname{ETS}\left(\mu 1 \mathrm{O}, \mathrm{h}^{-1} \mathrm{dm}^{-3}\right)$ & 1091 & 0 & 0.21 & 1.34 & 4.14 & 260.25 \\
\hline Chla $\left(\mathrm{mg} \mathrm{m}^{-3}\right)$ & 961 & 0.01 & 0.88 & 2.01 & 5.39 & 215.4 \\
\hline
\end{tabular}


summer to productive reservoirs with less alkaline waters (fig. 6a,b). Calcite supersaturation does not guarantee that precipitation of calcium carbonate is actually occurring, even less so co-precipitation of phosphorus, but it nonetheless indicates where such a process can take place.

$\mathrm{TN}$ is another regressor of chlorophyll- $a$ and, if the DIN:TRP ratio is sufficiently small (below 30 ), then TN is as good a predictor of chlorophyll- $a$ as TP (fig. $8 \mathrm{~b}$ ). In that case, however, both variables covary and regression analysis alone is insufficient to decide which nutrient, if any, is limiting algal biomass (DRAPER \& SMITH, 1981). Other variables explain small, if significant, amounts of the residual variance in the TP-Chlorophyll- $a$ relationship. These include water residence time and mean biomass of herbivorous crustaceans, both of them with negative coefficients.

The low correlation value between TP and Chla is not surprising. Correlations between biological variables are generally lower when computed on individual measurements than when the correlation coefficients are calculated on summer or 'growing season' averages. This is largely due to the fact that averages integrate the variability resulting from dynamic processes over time (HARRIS, 1986). The effect of herbivory on phytoplankton biomass, for example, can be totally dismissed if the temporal scale is inadequate (CARPENTER \& KITCHELL 1988, CARPENTER et al., 1991). These reasons partly explain the low coefficients of determination found in our regressions. Other causes can also be invoked: vertical heterogeneity, low range of variation in trophic state and, most importantly, the large multiplicity of stresses that reservoirs are subjected to.

Because so many factors affect phytoplankton productivity and biomass in Spanish reservoirs, any attempt to assign them a trophic state on the basis of this study should be taken with caution. The basic pattern, however, is robust at a regional scale. Figure 9 shows the reservoirs classified in four groups of increasing trophic state. The division in classes is conventional, but not arbitrary. It has been based on the concentration of phosphorus (TRP), and chlorophyll-a. Secchi disk transparency was not used because of the importance of abiotic turbidity. Morever, use of a multivariate index has been avoided because of its sensitivity to missing values, but the criterion used is in accordance with the multivariate structure of our data as outlined above. As expected, trophic state was only low in headwater reservoirs, and increased rapidly toward the lower reaches of each river. Moreover, the largest trophic state indices corresponded to reservoirs of low to moderate alkalinity.
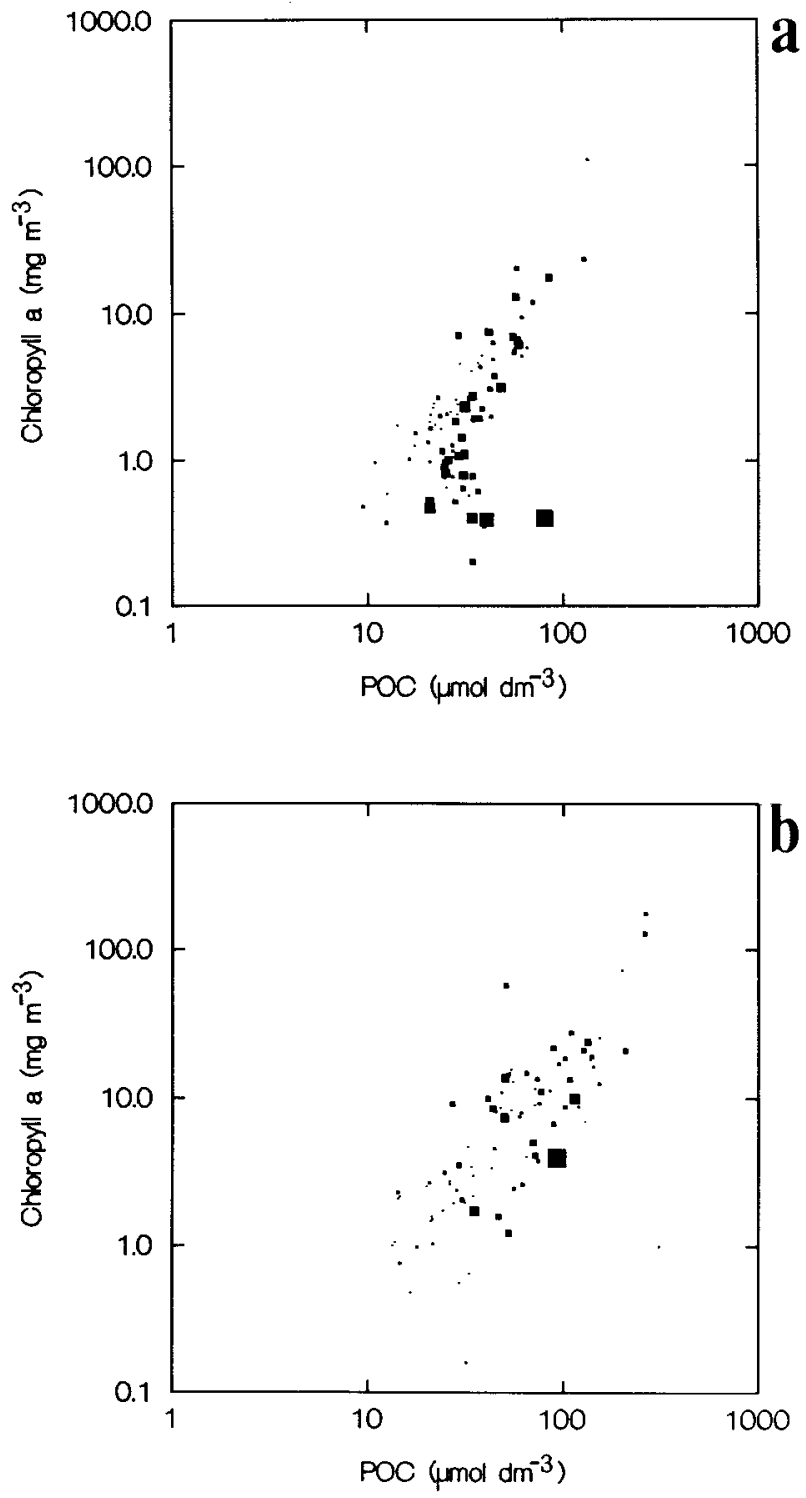

Figure 7. Relationship between photic zone chlorophyll-a and particulate organic carbon in (a) winter, and (b) summer samples. Symbol size is proportional to the logarithm of the concentration of total labile iron.

\section{PATTERNS OF VARIATION IN THE ABUNDANCE AND DISTRIBUTION OF PLANKTONIC ORGANISMS}

Patterns of variation in the distribution and abundance of phytoplankton, rotifers and crustaceans have also been explored using multivariate techniques (PCA, correspondence analysis, cluster analysis and discriminant analysis). Three key factors consistently appeared to explain a signifi- 

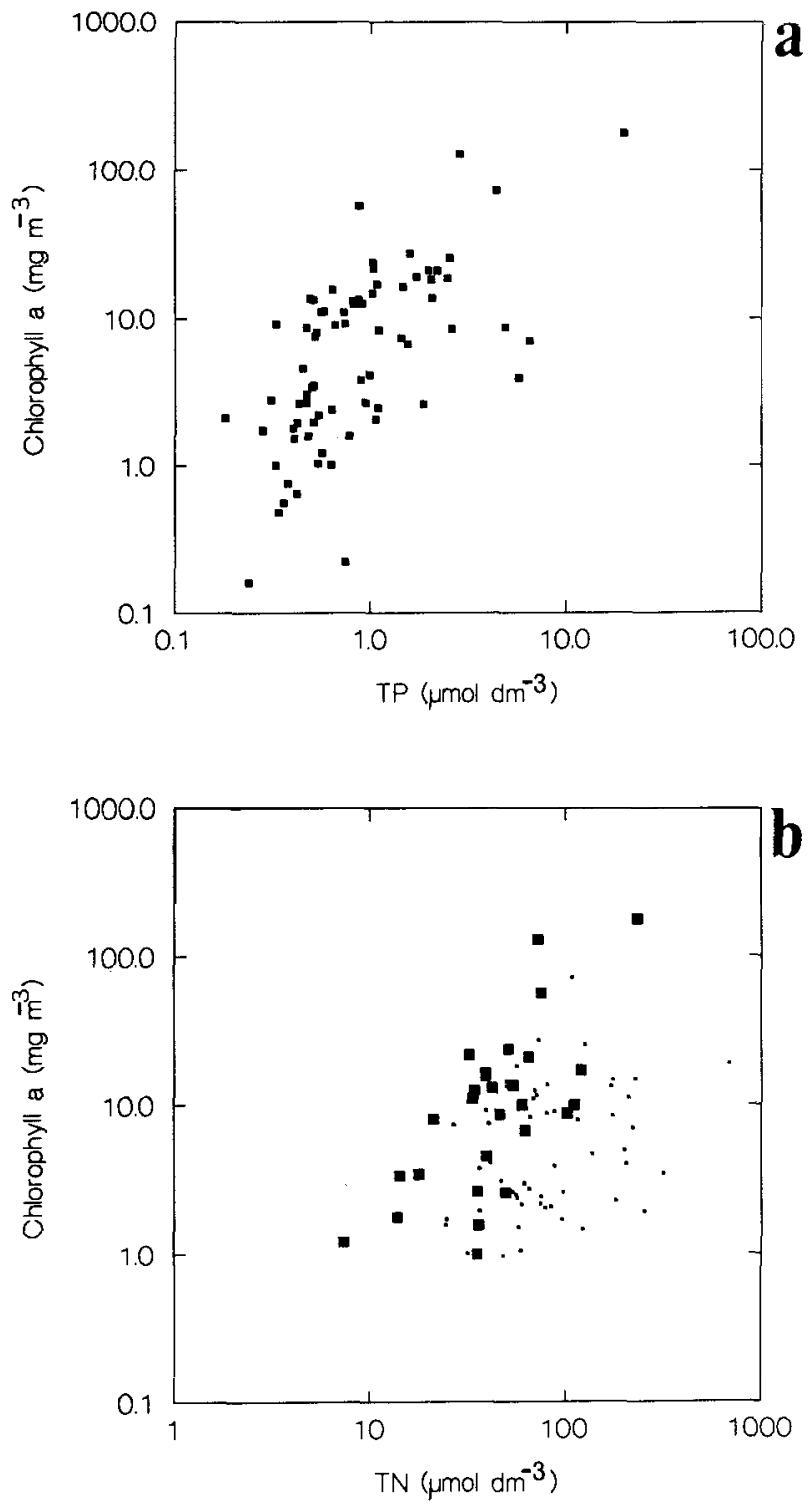

Figure 8. (a) Relationship between summer photic zone averages of chlorophyll-a and total phosphorus (TP). (b) Relationship between summer photic zone averages of chlorophyll-a and total nitrogen (TN). Dots represent reservoirs where DIN:TRP $>30$, whereas full squares correspond to reservoirs where DIN:TRP $<=30$.

caiii percentage of the variation in these three groups of organisms. These are, in order of explained variance, (1) the mineral content and alkalinity of the water, (2) the trophic state of the reservoir, and (3) the stability of the water column and the residence time of the water.

MARGALEF $\boldsymbol{e} \boldsymbol{t}$ al. (1982) and SABATER \& NOLLA (1991) consistently recognized the significance of these three factors in shaping the patterns of distribution of phytoplankton in Spanish reservoirs. Even though many of the taxa or groups of taxa were frequent and broadly distributed ( $\mathrm{Chroo-}$ monas sp., Cryptomonas sp. pl., Monoraphidium sp. pl.), showing a high tolerance with respect to the environmental factors under consideration, a few key taxa presented a disjoint distribution with respect to those factors. This was particularly conspicuous regarding the gradient of TDS content of the water. Aulacoseira distans, Tabellaria flocculosa, Cosmarium sp. pl., and others, characterized reservoirs with low alkalinity waters, whereas in reservoirs with higher TDS content, phytoplankton assemblages could be typified by the presence of Cyclotella sp. pl., Aulacoseira granulata, Ceratium hirundinella and Dinobryon divergens. Figure 10a portrays an example of a phytoplankton species which is restricted to the low-alkalinity reservoirs of northwertern Spain. Apart from the patterns of distribution, TDS content seems to affect cell size distributions, at least in populations of centric diatoms. Sabater (in press) found calcium concentration, together with temperature, to be the best regressors of cell diameter in Cyclotella radiosa and Cyclotella comensis, two species whose distribution is restricted to alkaline waters.

Along the gradient of TDS content, phytoplankton assemblages varied in relation to nutrient content. Moreover, MARGALEF et al., (1982), analyzing phytoplankton data from the winter sampling of 1974-75, also recognized turbulence as a third independent factor. Therefore, TDS content seems to be the most important factor explaining phytoplankton distribution but, having accounted for it, phytoplankton life-forms (sensu MARGALEF, 1978) appear to segregate according to nutrient content and turbulence, much in accordance with the model proposed by MARGALEF (1982). Thus, Asterionella formosa thrives in nutrient-rich, low-alkalinity mixed waters, whereas Cyclotella sp. pl. are primarily found in calcium-rich waters (MARGALEF, 1982; SABATER, 1991). An ordination of the reservoirs based on their phytoplankton composition (SABATER \& NOLLA, 1991) showed good agreement with ordinations produced using physicai-chemical variables.

About 120 rotifer taxa have been identified in plankton samples. Sixty of these taxa were euplanktonic, and, among these, 35 were common in the reservoirs studied. Overall, rotifers comprised a low biomass, sometimes as low as two orders of magnitude less than crustacean biomass (DE MANUEL \& JAUME, in prep.), although they may play a major role in nutrient cycling and energy transfer, as has been shown in lake ecosystems (MAKAREWICZ \& LIKENS, 1979).

Indirect gradient analysis of rotifer abundance data also revealed TDS content, nutrient concentrations and water residence time as key factors explaining the ecological 
segregation of different taxa (DE MANUEL \& ARMENGOL, in press). No distinct type communities could be found, but loosely formed assemblages, whose composition may vary rapidly in response to changes in environmental conditions, have been identified. Along the compound gradient of TDS content and aridity that extends from NW to SE Spain, different assemblages could be found, with distinct seasonal changes. Ascomorpha sp. pl., Gastropus stylifer, Synchaeta pectinata and Asplanchna sp. pl. were characteristic of alkaline reservoirs, while Ploesoma hudsoni, Collotheca sp. pl., Conochilus sp. pl. and Tricocerca cylindrica constituted an assemblage common in northwestern reservoirs. Moreover, water temperature played a significant role in relation with the geographic distribution of a few species. A number of warm stenothermous species appeared to be restricted to southern reservoirs (e.g. Brachionus falcatus and Filinia opoliensis), while Keratella tropica (fig. 10b) has extended its geographic distribution in comparison with the 1972-1975 study (GUISET 1977. DE MANUEL 1991).

The fauna of euplanktonic crustaceans is scanty in the Iberian peninsula, mainly as a result of the scarcity of true

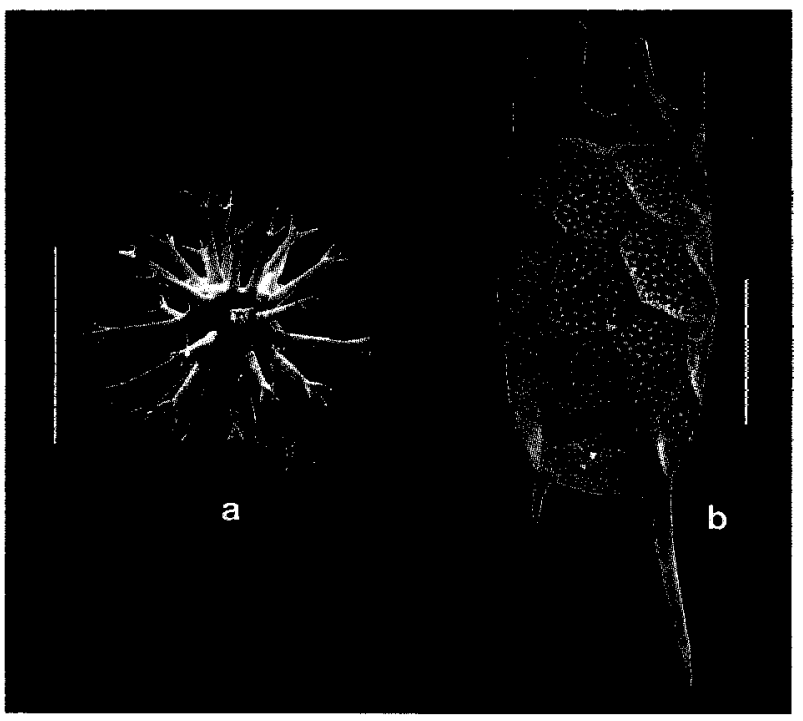

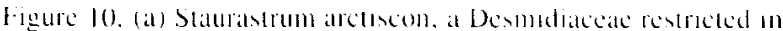
Spain to northwestern reservoirs, which have waters with low alkalinity and low TDS content. (b) Keratella tropica (Brachionidae), a warm stenothermous rotifer species that appears mainly in southern reservoirs. Scale bar, $50 \mu \mathrm{m}$. Scanning electron microscope photographs made at the Servei de Microscopia Electrònica of the University of Barcelona.

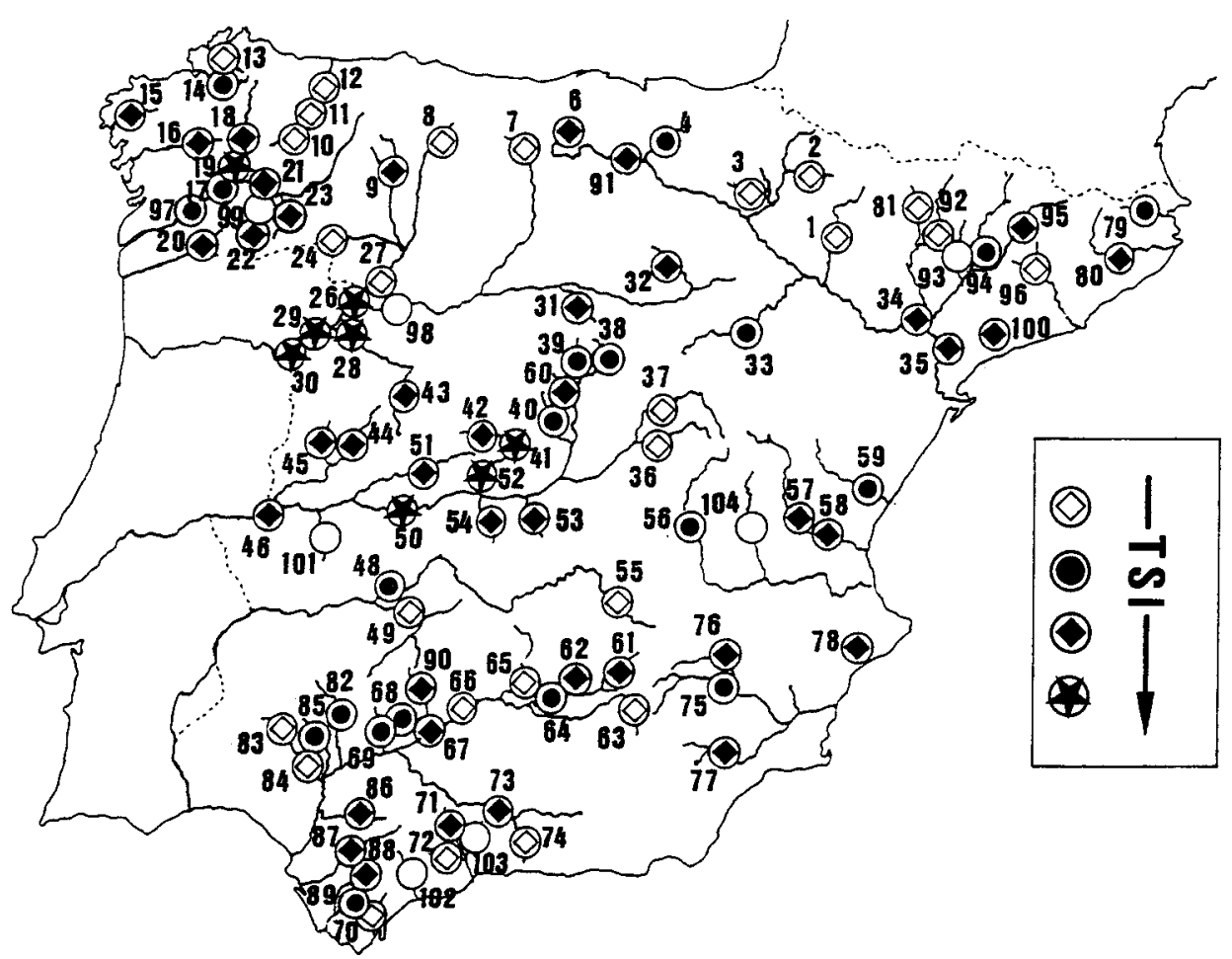

Figure 9. Map showing the reservoirs studied classified III groups of increasing trophic state. The trophic state index (TSI) was calculated from summer epilimnetic chlorophyll-a and TRP concentrations. For details, see MORGUI et al., (1990). 
limnetic habitats. Even though the extensive construction of reservoirs substantially increased the quantity of such habitats, only 28 euplanktonic species ( 15 cladocerans and 13 copepods) have been reported (ARMENGOL, 1978a), a number considerably lower than expected from studies in European lakes (MARGALEF, 1983). The fact that eight of these species had not been previously found in Spain (ARMENGOL, 1980), indicates the importance of reservoirs as new habitats for colonization. Ceriodaphnia cornuta, a species broadly dristrubuted throughout tropical and subtropical areas around the world, has been found in two reservoirs in southern Spain. On the other hand, cyclomorphic Daphnia (D. cucullata, D. galeata) appeared in northern reservoirs, possibly coming from Central-European lakes.

TDS content, trophic state and water residence time again appeared to explain a substantial proportion of the variance in crustacean data (ARMENGOL 1978b). Ecological segregation of species was often related to the compound gradient of mineralization and aridity. For example, the two species of Diaphanosoma (Ctenopoda, Sididae) found in Spanish reservoirs, D. brachyurum and D. mongolianum, show a clear allopatric distribution, the former being restricted to the north of the peninsula, and the latter to southern Spain (JAUME 1991). The residence time of water also affects crustaceans and, among all of the environmental factors considered, it is the best regressor of total crustacean biomass during the mixing period $\left(R^{2}=0.40, p<0.001, n=60\right)$.

\section{CONCLUDING REMARKS}

Interpretation of limnological data from studies at a regional scale is seriously affected by limitations at the spatial and temporal scales at which data acquisition is made. This problem is worsened by the fact that these studies have to deal with different levels of analysis, each of which has its particular scales of variability. Only when these scales are matched by the scales of data acquisition is the recovery of information possible (ALLEN \& STARR, 1982; FROST et al., 1989). Regional studies cannot, for this reason, efficiently recover the variace generated at short time scales or small spatial scales, and this variance is inevitably lost as uninformative noise. Countering this limitation, regional studies provide an opportunity to understand the hierarchical organization of limnological data and the interrelationships among the different levels of this hierarchy, let alone the massive body of descriptive data that they generate.
Our study of the regional limnology of Spanish reservoirs is a case in point. As we have seen, the landscape position of any particular reservoir, including the geology and land uses of its watershed, its position in the river and the climate of the region, largely determine the major ionic composition of its waters. Both the temporal and the spatial scales relevant at this level are large, and hence a very robust typology of Spanish reservoirs can be made. Nutrient concentrations are importantly affected by living organisms, but the general pattems of variation at the regional scale are still robust, revealing the importance of processes taking place in the watershed.

At the scale of planktonic organisms, interactions taking place within the basin prevail over external constraints. While the effect of the ionic composition and nutrient content of the waters, and ultimately that of landscape position and morphometry of reservoirs, still explain a significant proportion of the variation in the composition, abundance and geographical distribution of planktonic organisms, other processes operating at spacial-temporal scales dismissed by regional studies may have a much stronger effect.

\section{ACKNOWLEDGEMENTS}

Financial support has been provided by CICYT grant $\mathrm{n}^{\mathrm{o}}$ PB 85-0166 and sponsored by the Dirección General de Obras Hidráulicas of the Ministery of Public Affairs. J.L. Riera, D. Jaume and J.A. Morguí benefited from a FPI grant to participate in this project.

\section{REFERENCES}

ALLEN, T.F.H. \& T.B. STARR. 1982. Hierarchy. University of Chicago Press, Chicago.

ALONSO, M. 1985. Las lagunas de la España peninsular: taxonomía, ecología y distribución de los cladóceros. Ph.D. dissertation, University of Barcelona, Spain.

ALVAREZ COVELAS, M. 1982. Una limnología de la cuenca del embalse de El Vellón Madrid. Ph.D. dissertation, Univ. Complutense, Madrid.

ARMENGOL, J. 1978a. Los crustáceos del plancton de los embalses españoles. Oecologia Aquatica, 3:3-96.

ARMENGOL, J. 1978b. Zooplankton crustaceans in Spanish reservoirs. Verh. Internat. Verein. Limnol., 20:16521656.

ARMENGOL, J. 1980. Colonización de los embalses españoles por crustáceos planctónicos y evolución de la estructura de sus comunidades. Oecologia Aquatica,4:45-70. 
ARMENGOL, J., F. SABATER, J.L. RIERA, \& J.A. MORGUI. 1990a. Annual \& longitudinal changes in the environmental conditions in three consecutive reservoirs of the Guadiana river W. Spain. Arch. Hydrobiol. Beih., 33:679-687. ARMENGOL J.. J. CATALAN, N. GABELLONE, D. JAUME, J. DE MANUEL, J.A. MORGUI, J. NOLLA, J. PEÑUELAS, M. REAL, J.L. RIERA, S. SABATER, F. SABATER, \& J. TOJA. 1990b. A comparative limnogical study of the Guadalhorce reservoirs system Málaga, SE Spain. Scientia Gerundensis, 162:27-41.

ARMENGOL, J, J.L. RIERA, \& J.A. MORGUI. 1991. Major ionic composition in the Spanish reservoirs. Verh. Internar. Verein. Limnol., 24:1363:1366.

BOYLE, E.A., J.M. EDMOND, \& E.R. SHOLKOVITZ. 1977. The mechanism of iron removal in estuaries. Geochim. Cosmochim. Acta 41:1313-1324.

CARPENTER, S.R. \& J.F. KITCHELL. 1988. Consumer control of lake productivity. BioScience, 38:764-769.

CARPENTER, S.R., T.M. FROST. J.F. KITCHELL, T.K. KRATZ, D.W. SCHINDLER, J. SHEARER, W.G. SPRULES, M.J. VANNI, \& A.P. ZIMMERMAN. 1991. Patterns of primary production \& herbivory in 25 North American Lake Ecosystems. In: Comparative analyses of ecosystems J. Cole, G. Lovett, S. Findlay, eds.. Springer Verlag, New York, pp. 67-96.

DE MANUEL, J. 1991. Distribution of the Brachionidae Rotifera:Monogononta in Spanish reservoirs. Verh. Internat Verein. Lirnnol., 24:2741-2744.

DE MANUEL, J. \& J. ARMENGOL. in press. Rotifer assemblages: a contribution to the typology of Spanish reservoirs. Hydrobiologia.

DE MANUEL J. \& D. JAUME. in prep. Zooplankton from reservoirs of the Guadalquivir river basin Spain.

DIRECCION GENERAL DE OBRAS HIDRAULICAS 1988. Inventario de Presas españolas, 1986. M.O.P.U. Madrid.

DRAPER, N. \& H. SMITH. 1981. Applied Regression Analysis, 2nd Ed. Wiley, New York.

FROST, T.M., D.L. DEANGELIS, S.M. BARTELL, D.J. HALL, \& S.H. HURLBERT. 1988. Scale in the design \& interpretation of aquatic community research. In: Complex interactions in lake ecosystems S.R. Carpenter, ed.. Springer-Verlag, New York.

GABELLONE, N.A. \& C. GUISANDE. 1989. Relationship between texture $\&$ fractions of inorganic phosphorus in the surface sediment of a reservoir. Aquatic Sciences, 51:306-316.

GIBBS, R.G. 1970. The mechanisms controlling world water chemistry. Science, 170:1088-1090.
GALVEZ. J.A., F.X. NIELL, \& J. LUCENA. 1989. Seston vertical flux model for an eutrophic reservoir. Arch. Hydrobiol. Beih., 33:9-18.

GUISET, A. 1977. General distribution of planktonic rotifers in Spanish reservoirs. Arch. Hydrobiol. Beih., 8:222-225.

HARRIS, G.P. 1986. Phytoplankton Ecology: Structure,

Function \& Fluctuation. Chapman \& Hall, London.

JAUME, D. 1991. The genus Diaphanosoma Ctenopoda: Sididae in Spain. Hydrobiologia, 225:23-35.

KRZANOWSKI. W.J. 1988. Principles of Multivariate Analysis: A User's Perspective. Clarendon Press, Oxford.

LOPEZ, P. \& J.A. MORGUI. 1992. Phosphate \& calcium carbonate saturation in a stratified coastal lagoon. Hydrobiologia, 228:55-63.

MAKAREWICZ, J.C. \& G.E. LIKENS. 1979. Structure \& function of the zooplankton of Mirror Lake. New Hampshire. Ecol. Monogr., 49:109-127.

MARGALEF, R. 1978. Life-forms of phytoplankton as survival alternatives in an unstable environment. Oceanol. Acta, 1: 493-509.

MARGALEF, R. 1983. Limnología. Omega, Barcelona.

MARGALEF, R., D. PLANAS, J. ARMENGOL, A. VIDAL, N. PRAT, A. GUISET, J. TOJA, \& M. ESTRADA 1976. Limnología de los embalses españoles. Dirección General de Obras Hidráulicas, Ministerio de Obras Públicas, Publ. n. 123. Madrid.

MARGALEF, R., M. MIR, \& M. ESTRADA. 1982. Phytoplankton composition \& distribution as an expression of properties of reservoirs. Can. Wat. Res. .J., 7:26-50.

MORGUI, J.A., J. ARMENGOL, \& J.L. RIERA. 1990. Evaluación limnológica de los embalses españoles: composición iónica y nutrientes. Comunicacions /II Jornadas Españolas de Presas. Barcelona.

MOYA, G. \& G. RAMON. 1981. Características limnológicas del embalse de Cúber Mallorca. Actas del Primer Congreso Español de Limnologia, Barcelona, pp. 83-92.

O'NEILL, R.V., D.L. DEANGELIS, J.B. WAIDE, \& T.F.H. ALLEN. 1986. A hierarchical concept of ecosystem. Princeton University Press, Princeton.

ORTIZ, J.L. \& R. PEÑA. 1984. Applicability of the OECD eutrophication models to Spanish reservoirs. Verh. Internat. Verein. Limnol.,22:1521-1535.

OTSUKI, A. \& R.G. WETZEL. 1972. Coprecipitation of phosphate with carbonates in a marl lake. Lirnnol. Oceanogr., 17:763-767.

PACKARD, T.T. 1985. Measurement of electron transport activity of microplankton. Adv. Aquatic Microbiology, 3:207-261. 
PICAZO, M.T. \& G. LEMEUNIER, eds. 1990. Agua y nzodo de producción. Crítica, Barcelona.

RIERA, J.L., E. MARTI. \& J.A. MORGUI. 1991. Changes in the trophic state of the Spanish reservoirs during the last sixteen years. Verh. Internat. Verein. Limnol., 24:1367-1370.

RIERA, J.L. \& J. ARMENGOL. in prep. Relationships between seston composition \& water transparency in Spanish reservoirs.

SABATER, S. \& J. NOLLA. 1991. Distributional patterns of phytoplankton in Spanish reservoirs: First results \& comparison after fifteen years. Verh. Internat. Verein. Limnol., 24:1371-1375.

SABATER, S. 1991. Size as a factor in centric diatoms distribution:the Spanish reservoirs as an example. Oecologia aquatica, 10:45-60.
SIGG, L. 1985. Metal transfer mechanisms in lakes; the role of settling particles. In: Chemical Processes in Lakes W. Stumm, ed.. Wiley-Interscience.

STUMM, W. \& J.J. MORGAN. 1981. Aquatic chemistry. An introduction emphasizing chemical eyuilihria in natural waters. 2nd ed. J. Wiley \& Sons, New York.

TOJA. J. 1984. Limnología de los embalses de abastecimiento de agua a Sevilla. Servicio de Publicaciones de CEDEX, M.O.P.U., Madrid.

VIDAL, A. 1969. Evolution d'un lac de barrage dans le NE de 1'Espagne pendant les quatre premières années de service. Verh. Internat. Verein. Limnol., 17:191-200.

VIDAL, A. 1973. Development et evaluation du phytoplancton dans le reservoir de Sau. XI Congress Int. Comm. Large Dams, Madrid. 